\title{
OTTOMAN MACEDONIA BETWEEN THE POLITICS OF THE YOUNG TURKS AND THE KINGDOM OF SERBIA: EXPECTATIONS AND NEGOTIATIONS
}

\author{
MAKEDONKA MitROVA
}

\begin{abstract}
Makedonka Mitrova, Ottoman Macedonia between the politics of the young Turks and the kingdom of Serbia: expectations and negotiations.

The aim of this article is to analyze the politics of the Serbian Kingdom towards the newly created situation in Ottoman Macedonia, caused by the Young Turks Revolution in 1908. The activities of the Serbian Chetnik organisation in Ottoman Macedonia were discontinued, and instead a Serbian political organization was established. This organisation was mostly interested in the following agenda: regulating the status of the so called "Serbian people" in the Ottoman Empire; regular use of the national name "Serb" instead of the general term "Rum"; expansion of the patriarchies privileges to the "Serbs" in Ottoman Macedonia, and etc.
\end{abstract}

Keywords: Serbia, Young Turks Revolution, Serbian Political Organization, Bogdan Radenkovic, Ottoman Macedonia

Balcanica Posnaniensia. Acta et studia, XXI, Poznań 2014, Wydawnictwo Instytutu Historii UAM, pp. 121-136, ISBN 978-83-63047-59-7, ISSN 0239-4278. English text..

Makedonka Mitrova, Institute of National History, Skopje, Macedonia, m.mitrova@yahoo.com.

\section{THE YOUNG TURKS REVOLUTION: TROUGH ITS ROOTS AND OUTCOMES}

The Ottoman Empire at the end of the 19th century and the beginning of the 20th century was turned into a semi-colonial state. The absolute regime of Abdul Hamid II generated feudal social-economic relations that caused directly further legging behind of the overall development of the Empire. The initial forms of the capitalist production relations due to the absence of legislation were not able to spread and to become more dynamic. Hence, also the process of creating a new layer of citizens that would have unavoidably caused changes in the social-political system stagnated. The western states via a system of concessions, loans as well as by opening banks managed to take over the financial developments in the Empire. The biggest imperial Ottoman bank, serving as the state's central bank, was under the British-French control. The Ottoman Public Debt Administration (OPDA) also played a special role in turning the Empire into a semi-colonial state. It was established by the western states, after bankruptcy was declared in 1881, and the Administration had a right to take one 
third of the total income of the state. With this institution a parallel system of population exploitation and impoverishment was established. ${ }^{1}$

Under such economic-social conditions, part of the Ottoman social structure (lead by the Young Turk movement) strived towards unifying all different discontents in order to overthrow the sultan's system of Abdul Hamid II. ${ }^{2}$ The Young Turk movement in Ottoman Macedonia was initially oriented towards attracting Muslim military and civil intelligence. Thessaloniki, as the most cosmopolitan town in Ottoman Macedonia was the centre of discontent among the young Ottoman military elite. The officers of the III Army stationed in this city, who, due to the big debt of the state, had not been paid and promoted to higher ranks regularly. ${ }^{3}$ This was also an attempt to get rid of the tutorial attitude and interference of the great European powers in the internal affairs of the Ottoman Empire.

However, Ottoman Macedonia for some time was also the centre for organising the resistance of the Macedonian population against the absolutistic regime. This was also accompanied by the strong presence of the Balkan paramilitaries in this Ottoman region (especially after the 1903 Ilinden Uprising was suppressed) that brought the general situation up to a boiling point. Due to the presence and terror of the paramilitaries of the neighbouring states, the so-called "Macedonian question" at the beginning of 1908 entered probably its most critical phase, and once again it spread abroad. It became the reason for the great discord among the great European powers, especially after Austro-Hungary gained a permission to constructing the Thessaloniki Railway that meant placing Ottoman Macedonia under the indirect control of AustroHungary.

Having the "Macedonian question" once again in focus, the strengthening and spreading of the Young Turk movement especially in Ottoman Macedonia, forced Sultan Abdul Hamid II, being in need of military assistance, to offer Austro-Hungary a military treaty. Since their economic-political interests had been threatened by the Austro-Hungarian expansion to the Balkans, Great Britain and Russia were forced to coordinate their actions in order to protect their interests on the Balkan Peninsula. At the beginning of June 1908 in Reval, there was a meeting between the British King Edward VII and the Russian Tsar Nikolas II $^{4}$. At the Reval meeting they agreed on a reforming project for Ottoman Macedonia that envisaged placing it under international control, introduction of international military contingent and appointing an international governor, which made the separation of Macedonia from the Ottoman state realistically possible. ${ }^{5}$

${ }^{1}$ В. И., Шпилькова Младотуреикая револуция 1908-19092, Москва 1977.

2 See: M. Mazower, The Balkans, London 2000, p. 95.

3 J. Хамза, Турско-македонските односи во периодот 1850-1912, Скопје 1988, p. 160.

${ }^{4}$ Reval is today's Tallinn, the capital of Estonia.

${ }^{5}$ See: Р. Попов, Австро-Унгария и реформите в Европеиска Туриия 1903-1908, София 1974, p. 178-198; Г. Тодоровски, Реформите на големите европски сили во Македонија (1829-1909), по 3, Скопје 1984, р. 314-321; Ј. Донев, Македонија во британско-руските односи 1907-1908, Скопје 1994, p. 123-141. 
The implementation of the British-Russian plan which violated the sovereignty of the Ottoman state, according to the Young Turks, could have been implemented only by removing the incapable and corrupted sultan's regime and replacing it with constitutional democracy in the Empire. They believed that it was the time when if the political opportunity was missed there was a danger for Macedonia to be cut off the Ottoman state or to fall into the hands of the European states. This reason was also one of the many factors for the Young Turks movement to speed up their preparations for organising the insurrection to overthrow the sultan's regime. ${ }^{6}$ Hence, the Young Turks decided to prevent these two possible alternatives. The Young Turks Committee "Unity and Progress" sent a Memorandum to the Great Powers through their diplomatic representatives in Bitola in May 1908. The Memorandum stated:

\begin{abstract}
...We would like to inform you that Macedonia is part of the Ottoman Empire from all aspects ... Macedonia has been exposed to great pressure by the authorities. We shall eliminate that pressure without the interference of Europe. However, if Europe wants to help us and to help the humanity then it should give up any initiatives... In order to be able to put an end to that governance, it should impose pressure on Sultan Abdul Hamid II and the governments in Sofia, Athens and Belgrade. This is the path that could ensure peace and safety in Macedonia ... We feel free to inform you that we have no more patience ... ${ }^{7}$
\end{abstract}

Russia was the only state which did not receive the Memorandum. This was due to the fact that according to the Young Turks it was the main culprit for the situation in Macedonia. This Memorandum was the herald of the Young Turk Revolution that started on 3 July 1908, soon after the Anglo-Russian agreement in Reval. ${ }^{8}$ The Young Turk Revolution challenged the great European powers and Balkan states with completely new issues that needed resolving. ${ }^{9}$

At the time the most important reaction at the international political scene was the declaration of independence by Bulgaria and the annexation of Bosnia and Herzegovina by Austria-Hungary, which happened in a coordinated and simultaneous manner on 22 and 23 September 1908 (old style). ${ }^{10}$ On 23 September the island of Crete

${ }^{6}$ Ю. А., Петросян, Младотурецякое движение (втораО人 половина XIX - началото XX в.) Москва 1971, р. 281.

7 J. Хамза, Турско-македонските односи...,p. 162.

${ }^{8}$ After it was approved by the Young Turk Committee in Bitola, the Revolution started on 3 July 1908, after the Resen Garrison Commander, Ahmed Niyazi Bey fled to the mountain with 160 soldiers. Soon Niyazi Bey was joined by other officers and soldiers from the garrisons in Western Macedonia. His small rebellion unit in the first week reached a number of 500 troops and by the end of the third week 2000 . Three days after the uprising by Niyazi Bey, Major Enver Bey, an officer in Hilmi Pasha's Headquarters of the Thessaloniki garrison with his unit of 800 soldiers fled and went to Tikves. - J. Хамза, Турскомакедонските односи..., p. 166.

${ }^{9}$ See: L. Stavrijanos, Balkan posle 1453, Beograd 2005, p. 503.

${ }^{10}$ С. Стефанова, Международни актове и договори, София 1958, p. 311-312. Shortly after the victory of the revolution the Young Turks expressed their interests. Using the press and other means they opened the issue of having also Bosnia and Herzegovina, Rumelia and Cyprus participating in the elections, and the allusions went as far as Egypt, Tunisia and Algeria. Among the other reasons this was also 
also declared its annexation to Greece. ${ }^{11}$ This is how a new diplomatic crisis, known as the Balkan Annexation Crisis began (1908-1909). Also the issue of the mutual relations between the Serbian and the Bulgarian states became a European issue i.e. it was incorporated into the politics of the European great powers. The Bulgarian and the Serbian governments were no strangers to mutual alliance: for the Kingdom of Serbia, the Serbian-Bulgarian alliance should have strengthened the position of Belgrade in its struggle against Vienna and guaranteed Northern Macedonia as a sphere of Serbian influence; whereas for the Bulgarian state the agreement would have been important for its politics towards the Ottoman state i.e. to pressure Constantinople into resolving the Bulgarian-Ottoman dispute. ${ }^{12}$ The attempt for an agreement between the two states during the Balkan Annexation Crisis (1908-1909) ended in failure. The main reason was the inability of both governments to agree on a joint solution in regard to Ottoman Macedonia.

\section{THE KINGDOM OF SERBIA: TOWARDS POLITICS OF CHANGES}

The new phase in the political development of Ottoman Macedonia that happened with the Young Turk Revolution forced also the foreign policy of the Serbian government to take into consideration the changes in Macedonia that were underway. This task was given to an eminent diplomat at the time, Milovan Milovanovic, who was the Minister of Foreign Affairs. During the first days of the so called Hurriyet he gave instructions to all the Serbian diplomatic representatives, propaganda - political activists and supporters in the Empire, how to act in regard to the changes that had happened. The essence of the instructions is evident from the following quotation:

The unclear situation in the Ottoman state and the undetermined conduct of the other states that are engaged in the Ottoman affairs force us not to participate in these affairs in the Empire ... The formula for the conduct of our compatriots towards the events would be to be as reserved as possible, and if utterly necessary friendly neutral. ${ }^{13}$

the reason for Austria -Hungary and Bulgaria to act in a coordinated manner against the Young Turks aspirations for the stated territories.

${ }^{11}$ At the same time also the Greek population of Crete made an attempt to get rid of the vassal status and to become part of the Greek state, but there was resistance from the Ottoman state and the great powers, where the latter had openly a great control over the island. The Crete question was resolved in 1912. It kept the Ottoman state and Greece in constant tension that had negative repercussions on the internal political life in Ottoman Macedonia. - Ј. Донев, Македонија во..., p. 153.

12 The unilateral act by the Bulgarian state declaring its independence practically meant liquidation de jure of the last remaining Ottoman financial obligations. The Ottoman-Bulgarian tension that for some months was burdening the relations between the two neighbours ended in April 1909 with the mediation of Russia.

${ }^{13}$ State Archive of Macedonia (SAM), Скопје, m. 332, PE. no 3777. This instructions were send to Vlada Lotic in Solun/Thessalonica, Zivoin Balugdzic in Skopje/Uskub, Ljubomir Mihailovic in Bitola/ Monastir, Milan Pecanac in Prishtina and the Serbian diplomatic centre in Constantinople. 
Following these instructions in July 1908, when the new Ottoman Constitution was adopted, the Serbian diplomats in Macedonia kept a low profile, in a reserved and passive manner, waiting for the further development of the situation. From this period of the Serbian "friendly neutrality" an interesting record among the documents is the conversation between the Skopje Vali and the Serbian Consul to Skopje. Among others this conversation only confirms that in essence the creation of the Serbian Chetnik Organization (SCO) in Ottoman Macedonia had no "liberation" component. ${ }^{14}$ In this conversation the Vali pointed out to the Serbian diplomat that the failure to legitimise the Serbian armed units (cheti), even after the adoption of the Constitution, had a negative influence on the attempts to calm down the situation in the Ottoman state. The Serbian diplomat responded that there were not too many Serbian (paramilitary) units in Macedonia and that they would be definitely unarmed and withdrawn from the Macedonian territory. The only condition for this was the timing - immediately after the legitimisation of, according to him, the so-called "Bulgarian units". The Serbian armed units on Macedonian soil, as the consul stated, "existed only because of them". ${ }^{15}$ In addition, the Vali continued with a series of accusations against Serbia. He stated:

you are working on having Macedonia annexed to Serbia. The Young Turks as liberal patriots see you as their opponents because you have been the real enemy of the integrity of the Ottoman Empire. ${ }^{16}$

Furthermore, the Vali continued with his harsh and critical remarks regarding the official policy of the Kingdom of Serbia towards the Ottoman state. He emphasised that there was:

another reason for Young Turk's opposing Serbia. And, official Serbia and 'the Serbs' (referring to the Serbian Patriarchists in Ottoman Macedonia - M.M.) had friendly policy towards the Sultan. Hence, the Young Turks see you, 'the Serbs', as a pillar of the old regime. ${ }^{17}$

These words of the Skopje Vali clearly point out to the Serbian Government that the danger of straining the relations with the Young Turks was evident. For those reasons the Serbian state had to be careful with the particular political developments in the Ottoman Empire. Hence, the Minister M. Milovanovic approved the proposal by his diplomats in Macedonia to legalise the Serbian armed units:

...In regard to the Chetnik activities, this issue was resolved with their discontinuation or gradual termination ... The latest movement in the Ottoman state is much stronger than the Chetnic activi-

14 The Serbian Chetnik organization was established in 1902 in Belgrade. At the end of 1903 it started working on its structure in Ottoman Macedonia. It was a paramilitary formation of the Serbian state with a sole objective: taking over and annexing the Macedonian territory.

15 SAM, m. 332, PE. no 675, (23. VII 1908 )

16 Ibid.

17 Ibid. 
ty. So it is utterly natural for the units to be withdrawn spontaneously, faced with the stronger movement. ${ }^{18}$

Apart from the demilitarization process of the Serbian chetas in Macedonia, there were other manifestations that were summarised as friendly congratulations to the Young Turks for their "successfully finalised liberation mission."19 The Serbian consuls and agents in Ottoman Macedonia announced cooperation with the Young Turks on the forthcoming parliamentary elections. After this expression of loyalty they presented the Young Turks with their demands. First and the most important was to gain the full equality of the "Serbs" in regard to their legal (millet) position with the other ethnic groups ("narodnosti") in the Empire. This equality was to be expressed by official recognition of the separate "Serbian" millet in Macedonia. The Serbian part also expected the direct support by the Young Turks in appointing a national Serbian Bishop in the Veles-Debar Eparchy, proportional representation in the public administration and a possibility for gaining seats in the Parliament. ${ }^{20}$

\section{SERBIAN POLITICAL ORGANISATION IN OTTOMAN MACEDONIA: OPTIONS AND OPPORTUNITIES}

After the legitimisation of the Serbian units, the Chetnik organisation "Serbian Defence" was transformed into an Organisation for legal political activity. ${ }^{21}$ However, the new organisation needed involvement of civil-intellectual groups, the supporters

\footnotetext{
18 Г. Тодоровски, Српските конзули во Македонија за Младотурската револуција од 1908 година, «Гласник на ИНИ», IX/1, Скопје 1965, p. 200.

${ }^{19}$ М. Пандевски, Македонското ослободително дело во ХІХ и ХХ век, vol. 4, Скопје 1987, 288.

20 SAM, m. 346, PE. no 3995 (21. VII 1908); М. Пандевски, Политичките партии и организации во Македонија (1908-1912), Скопје1965, p. 243. After the adoption of the Constitution of the Empire there was a meeting at the Ministry of Foreign affairs of the Kingdom of Serbia attended by all the Serbian diplomatic representatives in the Ottoman state. At the meeting they discussed about the future policy of the Serbian government towards the Empire and about the rights and the privileges that the Serbian representatives should fight for in the Ottoman state. Among others it was decided: a) for the Skopje, Prishtina, Peja, Stari and Novi Pazar sanjaks as well as the Veles-Debar eparchy to be kept solely under the influence of the Kingdom of Serbia; b) The relations between the Kingdom of Serbia and the Ottoman state had to be peaceful, as the political and economic interests of the Kingdom of Serbia imposed; c) Also cooperation with the Bulgarian Political Clubs was envisaged. Apart from this the political programme also encompassed other issues: schools, churches, cultural activities of the "Serbs" in Macedonia, their economic strengthening and organizing. See: Ј. М. Јовановић, Јужна Србија од краја ХVIII века до ослобођењ $а$, p. 86-87. The main reason for the position of peaceful attitude towards the Ottoman state was probably the fact that at the time the Kingdom of Serbia was in customs war with Austria-Hungary, due to which the Kingdom had a great need of transit and customs exemptions through the Ottoman territory to the Thessaloniki port. - Д. Ђорђевић, Царински рат Аустро-Угарске и Србије (1906-1911), Београд 1962, р. 572-574.

${ }^{21}$ See: Српски књижевни гласник, year XXI, vol. VII, по 7, Београд 1908, p. 484.
} 
of the Serbian propaganda in Ottoman Macedonia. After a month long organisational preparations made by the consuls, the senior officials of the Rashka-Prizren and Skopje Mitropolitan's Dioceses as well as some activists, the so-called First Serbian Conference was convened. The Conference was held in Skopje between 10 and 13 August 1908 (old style) and there were 26 delegates participating in its work. All the most important representatives of the Serbian propaganda in Ottoman Macedonia, headed by the Serbian Metropolitan, attended this meeting. The attending delegates adopted a number of conclusions and determined the bases for the Serbian Political Organisation (SPO) also known as the "Serbian Democratic League". ${ }^{22}$ Giving such a name to the Organisation had the purpose of adapting the Serbian political activity to the context of the strivings of the liberal young Turks. ${ }^{23}$ The main objective of the "Serbian Democratic League" was to "unite the 'Serbian population' from all three vilayets (referring to the Kosovo, Bitola and Thessaloniki vilayets - M.M.) into a strong solidarity entity and to determine the direction of its work for the future" ${ }^{24}$ The most important document was the Manifest to the Ottoman Serbs, adopted on 11 August 1908 (old style). It underlined the following directions of action:

1. The Ottoman Serbs in the newly created circumstances shall abandon the work of the Chetnik organisation and they shall legitimise the overall activity.

2. They shall start creating a "Democratic league" that would work towards achieving "broad freedom, true equality and sincere brotherhood.'

3. The league shall recognise the territorial integrity of the Ottoman state as the bases for its future operation. $^{25}$

These premises had a purely declarative character and were more directed at the Young Turks than at the Macedonian population. At the Conference a Temporary Central Board of the League was elected (consisting of ten members), headed by Bogdan Radenkovic - an ex-Chetnik from SCO. ${ }^{26}$ Two Serbian Bishops were elected honorary presidents of the Central Board. The attending delegates decided for the headquarters of the Board and of the "Serbian League" to be in Skopje. "This city", as the Serbian Consul Zivoin Balugcic said:

...based on its geographical position and our national aspirations has been predetermined to serve as the starting point for the entire awakening and organising of the Serbian doctrine (srpstvoto) in this

22 SAM, m. 333, PE. no 768, (13. VIII 1908). The organisation used different names. Firstly starting from August 1908 it was called „Serbian Democratic League” or „Democratic League of the Ottoman Serbs", but few months later it was renamed to "Organisation of the Ottoman Serbs". At the beginning of 1910 it started using the name „Educational-Charity Organisation of the Ottoman Serbs”. Apart from these the following names were also used (even in the official correspondence): „Temporary Organisation of the Serbian People in the Ottoman Empire”, ,Serbian People Organisation in the Ottoman Empire”, „Serbian Clubs" as the opposite of the "Bulgarian Clubs", etc.

${ }^{23}$ SAM, m. 333, PE. no 768 (13 VIII 1908).

${ }^{24}$ М. Пандевски, Политичките партии..., 245-246.

${ }^{25} \mathrm{Ibid}, 244$.

${ }^{26}$ Историја српског народа, vol. I, Београд 1994, p. 331. 
region. Thus, the connection between Kosovo and the other parts of Old Serbia and Macedonia has been achieved, which we really need because in this region our rights have always been contested by the factual masters. ${ }^{27}$

The duty of the Temporary Central Board was to build an organisational network of the newly created organisation. The adopted Rulebook was especially important for the organisational structure and for the further development of the League. It envisaged the creation of vilayet (for the vilayets of Kosovo, Bitola, Thessaloniki and Skadar), county (in Prizren, Peja, Prishtina, Novi Varosh, Plevlje and Sjenica), district boards and municipal sub-boards of the League. ${ }^{28}$ The county boards in Ottoman Macedonia were planned only for Tetovo and Gostivar and they were directly subordinated to the Central Board in Skopje. Apart from this in regard to the districts in the Kosovo (Skopje) vilayet, the Central Board took over the competences also of their county board. The tendency in the Macedonian areas was obviously to have stronger centralisation in the management of the political activities. ${ }^{29}$

According to the instructions of the Serbian Government, the priority task of the Conference was to get involved in the upcoming parliamentary elections in the Ottoman Empire. Therefore, the first article from the Rulebook emphasised the task: the population needs to be prepared for the coming elections. ${ }^{30}$ The Temporary central board was assigned to provide its subordinate governing bodies with: translations of the Electoral Code, printed by the Serbian Royal Printing House; various guidelines; to place agitators in the Macedonian population, etc. The Rulebook, specially assigned the district boards of the League "to explain to their supporters the enormous benefit from taking part in the elections and the necessity for all the voters to cast their votes only for the candidates that had been previously supported by this organisation." ${ }^{11}$ All this allows to draw the conclusion that the Temporary Central Board in 1908 was as a matter of fact an electoral headquarter, and the whole SPO was turned into some kind of electoral machinery. Its greatest problem was who to address i.e. what would be the target population for the elections? In Ottoman Macedonian there was only the a small number of Serbian Patriarchists, and a very small percentage of them had their own property. The Electoral Code of the Ottoman state provided only for the citizens that owned property to have a right to vote (Article 11). According to this Article the citizens who were not taxpayers i.e. the workers, farmers

${ }^{27}$ SAM, m. 333, PE. no 785, (15. VIII 1908).

${ }^{28}$ Историја сриског народа, р. 332.

${ }^{29}$ М. Пандевски, Политичките партии..., 245-246.

${ }^{30}$ The Ottoman ruling circles made sure to limit the political struggles in the country within the narrow parliamentary framework. The first step in that direction was to announce the parliamentary elections that were anyway a very important event after the July changes. The election campaign was postponed for few months: from the beginning of August until December 1908. In several regions the population did not vote due to the lack of census registers (nufuzi). In mid November only half of the MPs were elected. The Peoples Parliament had its first session on 17 December 1908 (old style), with a significant delay. М. Пандевски, Политичките партии..., 249.

${ }^{31} \mathrm{Ibid}, 255$. 
and some other poor categories of people did not have a right to vote. ${ }^{32}$ The League's governing bodies in the course of the electoral campaign sent their agitators to the villages and towns to do a count of the adult males i.e. the potential voters and to prepare the electorate lists. The agitation involved more frequently the teachers and the voyvodas, and less the clergymen. ${ }^{33}$

The Temporary Central Board started negotiations for cooperation with the Young Turks' party "Unity and Progress" and the leitmotif of the negotiating process was agreeing of the Serbian seats in the Ottoman Parliament. ${ }^{34}$ After some bargaining during the negotiations, the Serbian political organisation in Ottoman Macedonia still managed to achieve an agreement with the Young Turks for joint appearance at the elections. Consequently, it joined a pre-electoral coalition thus ensuring at least some kind of chance to enter the future parliament. The Ministry of Foreign Affairs of the Kingdom of Serbia could not have been satisfied with this arrangement because SPO had to accept a subordinate position in the pre-electoral coalition. On the other hand, this was a rational decision because this Serbian political organisation did not have enough voters in Ottoman Macedonia. This reality check also becomes evident in the report by the consul in Skopje sent to the Ministry on 22 September 1908 (old style). ${ }^{35}$ The Serbian consul in his report concludes the following:

we cannot be fully satisfied with the results from the negotiations since we have sacrificed some of our national interests ... However, if we did not do that there would not have been an agreement and on our own, based on our numbers and the perspectives of the electoral programme of the Young Turks we would not have won any seats. ${ }^{36}$

Pointing at that weak Serbian status in regard to the electoral agreement with the Young Turks, the consul at the same time suggested to his Foreign Ministry that in his view this was another "uncertain solution". And that was an activity where: the Serbian Political Organisation in Macedonia should have tried to reach some agreement with the "Bulgarians". However, the Foreign Minister of the Kingdom of Serbia kept emphasising that the only option for the parliamentary elections was to reach an agreement only with the Young Turks and they should focus primarily on the election of the Serbian MPs in Skopje and Bitola ${ }^{37}$. Consequently agreement was concluded only with the Young Turks.

32 Ibid, 249.

33 SAM, Скопје, F. ГОООС-Скопје, уеar 1908, a.e. 1.

34 The Serbian Democratic League sent to Thessaloniki Bogdan Radenkovic, Jovan Shantric and Djordje Hadzi-Kostic to negotiate with the Central Young Turk Board. The Serbian demands were as follows: for the three non-Muslim "ethnic groups" - Serbian, Greek and Bulgarian - to get equal number of seats in the Ottoman Parliament. But the Young Turks refused that concept and they conditioned the electoral agreement with the Serbs with having an agreement on broader bases that would not have a national background. - Историја српског народа, р. 334.

35 Г. Тодоровски, Српските конзули во Македонија за.., р. 213.

36 Ibid, p. 214.

37 Ibid. 
In addition, the international affairs the ministry of foreign affairs was in favour of reaching an agreement with the Young Turks. During the Balkan annexationist crisis (1908-1909), Bulgaria on 22 September 1908 (old style) declared its independence. That influenced the changes in the position of the Young Turks towards the Bulgarian state and towards the Bulgarian Clubs in Ottoman Macedonia. Even stronger political blow for the Ottoman Empire came with the annexation of Bosnia and Herzegovina by the Austria-Hungary that happened on 23 September 1908 (old style). These two acts, that happened successively, constituted the violation of the 1878 treaty of Berlin. Namely, both the Ottoman state and the Kingdom of Serbia treated these successive acts as acts of aggression on part of Austria-Hungary and Bulgaria and they caused unrest among the official authorities and among the population of both states. On the other hand, these external events had a negative impact on the unsettled position in the Ottoman state in regard to the strengthening of the Young Turks achievements. Therefore, both the Kingdom of Serbia and the Ottoman Empire at the time found themselves in the same position in regard to the unilateral political acts of AustriaHungary and Bulgaria.

The political tension of the situation in the Ottoman state during the Balkan annexationist crisis (1908-1909) is also evident from the fact that at the meeting of the Central Board of the Young Turk Organisation in Thessaloniki held at the beginning of October 1908 the main topic of discussion was the attitude of the state authorities towards these two political issues. ${ }^{38}$ The President of Serbian Party, Bogdan Radenkovic, was sent as a representative to this meeting of the Central Board of the Young Turk Board. ${ }^{39}$

The agreement for the pre-electoral coalition secured for the Serbian Democratic League four seats in the Parliament from the Kosovo (Skopje) vilayet and one from the Bitola and one from the Thessaloniki vilayets. Still after the elections the electoral results were such that only Savo Stojanovic from the Prishtina, Aleksandar Parlic from the Tetovo and Janakie Dimitrievic from the Bitola vilayet got seats. ${ }^{40}$ For the Serbian League it was also very important that the Young Turks accepted the demand not to allow any other Serbian candidate not on the list established by the League to run for election. ${ }^{41}$

The agitating groups from SPO were supposed to inform people in villages about the constitutional changes and to channel their actions in the future. The orders by the Central Board were broader: people in villages to continue maintaining the existing organisational relations with their superiors, established before by the armed units; to create their own courts, headed by the voyvodas; to keep their weapons clean and well hidden, etc. This clearly shows the double game that SPO played with the Young

${ }^{38}$ SAM, Скопје, m. 334, PE. no 1026, without date.

${ }^{39}$ Ibid.

${ }^{40}$ И. Иванић, Маћедонија и Маћедонии, Novi Sad 1908, p.547; Историја српског народа, p. 335 .

${ }^{41}$ SAM, Скопје, F. ГОООС - Скопје, Letter from B. Radenkovic of Thessaloniki, 31. VIII 1908, a.e. 9 . 
TurksOn one hand, SPO joined the pre-electoral coalition in order to gain seats in the Parliament, and on the other hand, it did not give up its Chetnik judiciary and its Chetnik weapons in an attempt to derogate the Young Turk authority. Among others, the Serbian agitating groups advised their supporters "just like before" to remain "unchangeable Serbs" if they wanted to get greater freedom by the Hurriyet and for the armed units to collect the agreed membership fee, etc. All this shows that the Serbian political-propaganda organisation in Macedonia represented an addition to or a new copy of the same Chetnik organisation even though the Chetnik actions as an option were put aside for some time. The agitation directed especially at village population in the villages "not to trust any fraternising with the "Bulgarians" i.e. with the Macedonian population with Exarch church affiliation and to avoid any contacts with it. ${ }^{42}$ However, this order whose objective was to cause further division among the Macedonian population was difficult to realise in practice. the Macedonian peasantry in majority was free from the artificially implemented church-propaganda barriers (which at the same time were not ethnic but only church-political markers, were interconnected economically, through family and other traditional links and primarily through their common vernacular language. ${ }^{43}$

One of the more important demands that the Kumanovo peasants kept posing to the officials of SPO was the need of new schools. Many of the villages in Kumanovo, did not have schools so in a report by a "Serbian teacher" he suggested the urgency of this demand because in his view it was "the only way and a guarantee for the people in the villages to vote for our candidates and stay on our side (referring to the side of the Serbian propaganda - M.M.)." ${ }^{44}$ The issue of opening a new school was also pointed out by the citizens of Kumanovo.

Due to this problem in the summer of 1909 there was a harsh public conflict: the citizens of Kumanovo supporting the Serbian propaganda cut all their links with the local Serbian club, the Serbian church-educational authorities in Kumanovo and with the Consulate in Skopje. ${ }^{45}$ The conflict was so big that even the Metropolitan Vinkontie was forced to urge for "reconciliation between the two sides" and the President of SPO, B. Radenkovic came to Kumanovo and mediated in resolving the conflict. ${ }^{46}$ In fact the citizens of Kumanovo population demanded from SPO improvement of the social-economic situation i.e. satisfying the municipal needs which in the absence of some kind of municipal elections they had to pose as a demand for the parliamentary elections. However, it was questionable how much the representatives of

\footnotetext{
${ }^{42}$ М. Пандевски, Политичките партии и...,p. 256.

${ }^{43}$ See: Frederik Barth, Ethnik groups and boundaries. The social organization of culture difference, Oslo, Universitetsforlaget, 1969.

${ }^{44}$ SAM, Скопје, F. ГОООС - Скопје, The report from the teacher A. Chavdarevic of Kumanovo, 23. VIII. 1908, a.e. 3; The report by a group of teachers, 28. VIII. 1908, a.e. 6.

${ }^{45}$ Историја српског народа, р. 344.

46 М. Пандевски, Политичките партии и...p.257; SAM, Скопје, F. ГОООС - Скопје, year 1908, a.e. 17 .
} 
the Serbian as well as the Bulgarian propaganda (even though full of such promises) were willing and able to realise these demands of the local population.

The February Congress of SPO in Skopje in 1909 established that the Serbian activities in Macedonia in the eyes of the Greek Patriarchy was found as a "very serious opponent." ${ }^{47}$ At the same time it was pointed out that the Ottoman authorities did not grant equal rights and privileges to the Serbian metropolitans as the ones provided to the Greek. The SPO's Main Board formed at the Congress tasked its MPs to put forward at the Ottoman Parliament the issue of the use of all the Patriarchist privileges for the Serbian supporters in Ottoman Macedonia. ${ }^{48}$

The main goal for the general politics of the SPO in Ottoman Macedonia was the formation of a separate - Serbian millet within the Ottoman Empire. With this achievement in the time of the constitutional changes of the Empire, the Serbian national name could be recognised and officially used. This was of enormous importance for the activities of the Serbian propaganda in Ottoman Macedonia. The Ottoman authorities continuing the state tradition regardless of the positive provisions in the Constitution continued using the collective religious-church name of Rum millet for all the Serbian supporters in Macedonia and for the Serbian orthodox population in "Old Serbia". ${ }^{49}$ Hence, the abovementioned population was placed in the same category with the Greek, and with the Macedonian, Vlach and Albanian Patriarchists. The Main Board demanded for the authorities to replace this archaic denomination with the national name "Serbs", "the Serbian people", etc., and it instructed all the SPO's boards to act in that direction. ${ }^{50}$ The Serbs did not succeed in this during the Ottoman rule in Macedonia.

The Serbian Political Organisation in Macedonia was especially active in regard to the appointing of a Serbian Bishop to the Veles-Debar Patriarch Eparchy. This position was presented to the Greek Parteniy. The "Serbian" priests and teachers publicly and ostentatiously refused to recognize this Bishop as their religious leader. Finally, in the spring of 1910, after the state visit of the Serbian King to Constantinople, the Patriarchy appointed to this position the Serbian monk Varnava Rosic. ${ }^{51}$ The next task for the Serbian political-propaganda action in Ottoman Macedonia in this sense was to also get the bishop's position at the Ohrid Patriarch Eparchy. This act they be-

${ }^{47}$ М. Пандевски, Политичките партии и...,p. 256. 78 delegates attended the Congress and it was opened by the Skopje Bishop Vikentie. They adopted a Constitution renaming the SPO into an «Organisation of the Serbian People in the Ottoman Empire». The constitutional provisions defined the Organisation as distinctly nationalistic and bureaucratic-centrist one. The Congress as the most senior governing body elected the Main Board consisting of twelve members. Bogdan Radenkovic was re-elected as the President of SPO and of the Main Board.

48 SAM, Скопје, m. 333, РЕ. nо 3995.

${ }^{49}$ SAM, Скопје, m. 360, PE. no 1641. - On May 27th 1909 (old style) Stojan Zafirovic gave the following statement: "From the Report of the Central Board we can see that the Ottoman authorities have not recognised the name 'Serb', yet. Imagine, the official documents still use Rum or a Christian instead of Serb".

${ }^{50}$ М. Пандевски, Политичките партии и..., р. 258.

${ }^{51}$ Историја српског народа, р. 345. 
lieved would have meant final separation of the area of the Serbian aspirations from the Greek ones in Macedonia. ${ }^{52}$ This action of SPO clearly shows the political intention in regard to the church-administrative borders established with the millet system in Ottoman Macedonia to be redefined in the future as state (ethnic) borders.

In its activities in Macedonia the Serbian Political Organisation directed its efforts towards dealing with the church-school status quo introduced by Hilmi Pasha after the 1903 Ilinden Uprising. Within this context were also the guidelines of the Skopje consul Z. Balugdzic sent to all the Serbian consuls in Macedonia on 31 March 1909 (old style). He stated: "We should demand for the 1903 decision for a status quo to be revoked." 53 The provisions of the Hilmi Pasha status quo interfered with the attempts of the Serbian activists to take over (from the Bulgarian or the Greek propaganda) or to open new churches and schools especially in those Macedonian areas that were of interest to the Serbian state. ${ }^{54}$

All these issues were discussed at the February 1909 Congress of the Party, at which a specific political decision was made. This resolutions demanded the revision of the Empire's Constitution in order to regulate the final status of the "Serbian people" in the Ottoman state and to resolve its national issue; regular use of the national name of "Serb" instead of "Rum"; a decision by the Parliament for broadening the Patriarchists privileges without any limitations also to the Serbian Bishops; getting the Veles-Debar Metropolitan Diocese; revoking of the church-school status quo, etc. ${ }^{55}$ In order to achieve these demands the Serbian activists acted via the Sublime Porte, the Parliament and the Patriarchy in Constantinople. However, they were also active in Ottoman Macedonia gradually winning new positions or defending the ones they already had. So at the same time together with other agitating groups, even the Bishop Vikentie took a tour round the Kumanovo villages in August 1908. His mission was to open the churches that the Ottoman authorities had closed. During the tour he urged the peasants not to be afraid any more but to oppose those measures of the authorities. During the agitations the Serbian activists clashed with the Bulgarian Clubs leaders. There were especially harsh conflicts in the areas near the border region of their priority influence sphere of priority influence: south-west of Kumanovo up to Shtip, Veles, Prilep, Ohrid and Struga regions. ${ }^{56}$ The demarcation of the conflict zone between the those two propagandas emphasised their very essence i.e. the conflict (?) was aimed at moving this zone to the detriment of the opponent. ${ }^{57}$ In contrast to these actions

52 Српски књижевни гласник, vol. XXIV-XXV, Београд 1910, p. 797-798.

53 SAM, Скопје, m. 352, PE. nо 188.

54 See: G. W. White, Nationalism and Territory: Constructing Group Identity in Southeastern Europe, published in the United States of America, Rowan\&Littlefield Publishers, Inc. 2000, p. 226-228; M. Mitrova, "The Balkan Wars and Ottoman Macedonia:The Spatial Context of the National Programmes of Serbia,Greece and Bulgaria”, Prac Komisji Środkowoeuropejskiej PAU, tomieXXII, Krakow, 2014, 45-57.

55 М. Пандевски, Политичките партии и..., р. 259.

56 SAM, Скопје, m. 352, РЕ. nо 188.

57 М. Пандевски, Политичките партии и..., р. 260. 
SPO in the Kichevo region acted mainly against the Greek Veles-Debar Bishop in the course of 1910. In the Palanka, Veles and Prilep districts the Bulgarian-Serbian conflict turned into mutual lurking, frequent clashes and common insinuations with the Ottoman authorities. ${ }^{58}$ As a matter of fact even the declaration of the constitutional order of the Ottoman state did not help preventing the church-political struggles because the "proclaimed citizens" continued acting as the believers and subjects of the propaganda organ-isations in Ottoman Macedonia.

SPO also took part in the organised action of the Young Turks in Skopje boycotting the goods from Austria-Hungary and Bulgaria, persuading their supporters to participate in that. In these actions, even though for different reasons, SPO found itself in line with the Young Turk Party. But still the Serbian-Ottoman solidarity in crisis was of short duration. The Serbian Political Organisation in the direct contacts with "Unity and Progress" as well as via its representatives at the Parliament exerted pressure on the Sublime Porte for revoking the direct agreement with Austro-Hungary, and the dispute about Bosnia and Herzegovina was (?) taken to an international conference. This Serbian proposal was rejected by the Young Turk government. In the spring of 1909 when the Ottoman state finally recognised the annexation of Bosnia and Herzegovina by Austria-Hungary and the collaboration between the Young Turks and SPO on this issue ended.

The Macedonian historian Manol Pandevski insightfully concludes the following:

Even though the SPO leaders dedicated the least attention to the economic demands it was impossi-
ble to completely avoid them. In the report from the Congress in regard to the economic conditions
as well as in the adopted Resolution that dealt with these issues the following demands were posed:
dealing with and alleviating the ten percent tax system; return of the land taken from the Macedonian
peasants by force; buying out the big chiftlik properties in order to establish independent peasantry;
legal regulation of the rights and the duties between the chiftlik peasants and the beys; making the
loans more accessible to agriculture, trade, etc. ${ }^{59}$

The agrarian demands were stated in such an absolutely partial way, especially when one takes into consideration the Ottoman categorical firmness to them, that one could come to the conclusion that they were discussed solely for demagogic reasons. This conclusion can be also drawn from the fact that SPO did not carry out any action against the Ottoman beys for the purpose of resolving these problems.

In 1909 there were big changes for this political organization to function due to the new Young Turks' August Law on Associations, which prevented the existence of such a political organisation. ${ }^{60}$ Hiding behind this young Turk law, the Serbian con-

58 Ibid.

${ }^{59}$ Ibid. p.262.

${ }^{60}$ The Law on Associations was adopted on 3 August 1909 (old stile).by the Young Turks parliamentary majority. The provisions from this Law were of utter importance for the political life in Macedonia. According to Article 4: "it was forbidden to found political associations based on national or race differences or names." All the existing political organisations that had national trait had to be reformed or dis- 
suls in the Ottoman Empire, which ruled with SPO, started working on its systematic disbanding. At one of the meetings it was decided for SPO, in compliance with the law, not to announce its disbanding but to be transformed into an "Educational Charity Association". This decision was made on the basis of the suggestion by the Ottoman authorities, who proposed that political clubs should be transformed into a kind of educational boards. However, SPO even in such a form did not manage to survive much longer. The Serbian government also played a huge role in their dissolution because it stopped providing them with any assistance or financing. The Serbian political propaganda in Ottoman Macedonia continued to exist and operate using the methods from the time before the Hurriyet. Up until the Balkan wars (1912-1913) the Serbian propaganda continued to reinforce its church-educational structure, its economic penetration and functioning of the renewed Chetnik paramilitary actions.

banded. An article in the Law authorised only the State Council: to recognise the associations' usefulness which practically meant that the political associations could have existed but only under the Ottoman national name and to deal only with educational, cultural and economic issues and not political ones. This Law went into effect in November 1909.- М. Пандевски, Политичките партии.., р. 250. 
